\title{
Efektivitas Pengawasan Kelembagaan Dan Masyarakat Terhadap Kebijakan Penataan Ruang (Kawasan Cagar Alam Geologi Karangsambung)
}

\author{
Indraya Kusyuniadi ${ }^{1}$ dan Imam Buchori ${ }^{2}$
}

1 Magister Ilmu Lingkungan, Universitas Diponegoro, Semarang, Indonesia; e-mail: indraya kus@yahoo.co.id
2 Departemen Perencanaan Wilayah dan Kota, Fakultas Teknik, Universitas Diponegoro, Semarang, Indonesia

\begin{abstract}
ABSTRAK
Kawasan Cagar Alam Geologi Karangsambung (KCAGK) adalah kawasan yang mempunyai keunikan batuan dan fosil, sehingga mendapat julukan sebagai "Black Box" dari proses alam semesta. Berdasarkan kebijakan tata ruang (RTRW) menetapkan KCAGK sebagai kawasan strategis sebagai fungsi daya dukung lahan. Konsekuensinya adalah semua aktifitas yang dapat mengubah bentukan geologi dilarang. Akan tetapi kegiatan penambangan masih menjadi ancaman akan hilangnya keanekaragaman bebatuan yang dilindungi. Penelitian ini memfokuskan pada aspek pengawasan yang terindikasi masih lemah dalam penyelenggaraan pentaan ruang, melalui aspek kelembagaan dan masyarakat. Aspek kelembagaan terdiri dari Lembaga Ilmu Pengetahuan Indinesia (LIPI) dan pemerintah daerah melalui Badan Koordinasi Penataan Ruang Daerah (BKPRD), sedangkan aspek mayarakat diwakili tokoh lokal. Penelitian ini menggunakan pendekatan kuantitatif dengan teknik analisis studi statistik deskriptif. Proses penelitian diawali dengan menentukan jumlah populasi untuk lembaga LIPI dan BKPRD melalui purposive sampling diperoleh jumlah sampling sebesar 8 responden. Penentuan jumlah responden masyarakat yang diwakili tokoh masyarakat, menggunakan random sampling dengan teknik area probability diperoleh sampling sebesar 20 responden.Tahapan kedua adalah pengisian kuesioner melalui wawancara langsung ke responden. Tahapan ketiga adalah melakukan analisis efektivitas pengawasan kebijakan tata ruang melalui peran kelembagaan dan masyarakat. Hasil yang diperoleh dari penelitian ini adalah peran dari kelembagaan dan masyarakat belum efektiv dalam melakukan tahapan pengawasan Peraturan Daerah (Perda) RTRW di KCAGK. Indikator dari ketidak efektivan dilihat dari: 1) sosialisasi kebijakan, 2) perizinan penambangan, 3) penerapan insentif dan disinsentif, 4) pembiayaan dan 5) pemantauan dan kepedulian lingkungan. Perlu suatu perbaikan dalam meningkatkan peran kelembagaan dan masyarakat, diantaranya 1) Lembaga BKPRD perlu ditinjau ulang keberadaannya, 2) peran masyarakat perlu di berikan kewenagan lebih dalam pengawasan lingkungan di KCAGK.
\end{abstract}

Kata kunci: Kebijakan RTRW, Efektivitas, Pengawasan, Kawasan Lindung, Kelembagaan dan Masyarakat

\begin{abstract}
The Karangsambung Geological Nature Reserve (KCAGK) area is a region that has unique rocks and fossils, so that it has been called "Black Box" of the processes of the universe. The spatial policy (RTRW) establishes KCAGK as a strategic area as a function of land carrying capacity. The consequence is that activities that can change geological formations are prohibited. Mining activities still exist a threat to the loss of protected geodiversity. This research focuses on implemantation stage that are indicated to be weak in spatial planning process, through institutional and awareness from the community. The institutional aspect consists of the Indonesian Institute of Sciences (LIPI) and the local government through the Regional Spatial Planning Coordinating Board (BKPRD), while aspects of society are represented by local figures and miners. This study uses a quantitative approach with descriptive statistical analysis analysis techniques, in completing the analysis of research findings will be combined with a qualitative approach through observation and interviews. The research process begins by determining the total population for LIPI and BKPRD institutions through purposive sampling obtained by 8 respondents. Determination of the number of community respondents is grouped into 2 namely community leaders and miners. Using random sampling with a probability area technique for community leaders totaling 20 respondents. The second stage is filling in the questionnaire through direct interviews with respondents. The third stage is to analyze the effectiveness of spatial policy oversight through the role of institutions and communities. The results obtained from this study are the role of institutions and communities that are not yet effective in monitoring Regional Regulation (Perda) on the RTRW in KCAGK. Indicators of ineffectiveness can be seen from: 1) policy socialization, 2) mining licensing, 3) application of incentives and disincentives, 4) financing and 5) monitoring and environmental awareness. There needs to be an improvement in enhancing the role of institutions and the community, including 1) BKPRD institutions need to be reviewed their existence, 2) the role of the community needs to be given more authority in environmental monitoring at KCAGK.
\end{abstract}

Keywords: Spatial planning policies, Effectiveness, Supervision, Protected Areas, Institutional and Community

Citation: Kusyuniadi, I. dan Buchori, I. (2020). Efektivitas Pengawasan Kelembagaan Dan Masyarakat Terhadap Kebijakan Penataan Ruang (Kawasan Cagar Alam Geologi Karangsambung), 18(2), 209-217, doi:10.14710/jil.18.2.209-217 


\section{Pendahuluan}

Pembangunan wilayah merupakan suatu perwujudan dalam menciptakan pertumbuhan ekonomi yang berdampak pada kesejahteraan masyarakat, akan tetapi pertumbuhan ekonomi seakan menjadi tujuan utama dengan mengindahkan dampak dan keberlanjutan lingkungan. Pada akhir Tahun 80-an kondisi dimana lingkungan belum menjadi prioritas dibandingkan dengan pertumbuhan ekonomi dan sosial, perubahan mulai terjadi pada Tahun 1987 dengan munculnya konsep pembangunan berkelanjutan yang dituangkan dalam laporan Brundtland. Pengertian Konsep pembangunan berkelanjutan yaitu pembangunan yang dapat memenuhi generasi sekarang tanpa mengurangi generasi akan datang (Flores et al, 2017). Pandangan serupa tentang pembangunan berkelanjutan adalah kegiatan yang dapat memenuhi akan generasi sekarang tanpa mengurangi akan generasi mendatang adalah difinisi dari pembangunan berkelanjutan (Keeble, 1988).

Dalam mewujudkan pembangunan berkelanjutan, kita dihadapkan adaya konflik sektoral, yaitu: sosial, ekonomi dan lingkungan. Adanya interaksi sektoral sosial, ekonomi dan ekologi akan memunculkan konflik penggunaan lahan pada suatu lokasi tertentu menurut Campbell, (1996, dalam Dunk et al, 2011). Persoalan lingkungan dalam pembangunan berkelanjutan ini dipicu akan kepentingan ekonomi yang dianggap prioritas, sehingga kesejahteraan atau material adalah yang utama, terlebih pada keberpihakan pemodal besar. Anggapan akan lingkungan sebagai kebutuhan yang kurang penting, sehingga mamacu akan cara-cara eksploitatif dalam pemanfaatan sumberdaya alam yang ada (Absori, 2006).

Kepentingan atau pemanfaatan ruang yang dikelompokan menjadi 3 sektor sosial, ekonomi dan lingkungan masing-masing memiliki tujuan, diantaranya: 1) kepentingan sosial, dengan tujuan peningkatan kualitas hidup, kesejahteraan dan pemberdayaan, 2) kepentingan ekonomi, bertujuan pertumbuhan, pemerataan, stabilitas ekonomi dan efesiensi dan 3) Kepentingan lingkungan, tujuan berupa daya dukung dan daya tampung lingkungan untuk pelestarian alam. Kebijakan penataan ruang yang dituangkan dalam rencana tata ruang wilayah diharapkan menjadi acuan, arahan bagi pembangunan, hal ini sesuai dengan amanat UndangUndang Nomor 26 Tahun 2007 tentang Penataan Ruang. Seperti yang tertera pada gambar 1.

Kebijakan penataan ruang merupakan produk hukum yang dituangkan dalam bentuk peraturan perundang-undangan secara nasional maupun daerah (Arba, 2017). Pengertian mengenai rencana tata ruang dalam proses pelaksanaan dilakukan secara berkesinambungan, artinya proses pengawasan atau pemantauan, evaluasi dan peninjauan rencana tata ruang adalah sesuatu yang penting dalam menciptakan keefektivan perencanaan yang berkelanjutan (Segura \& Pedregal, 2017).

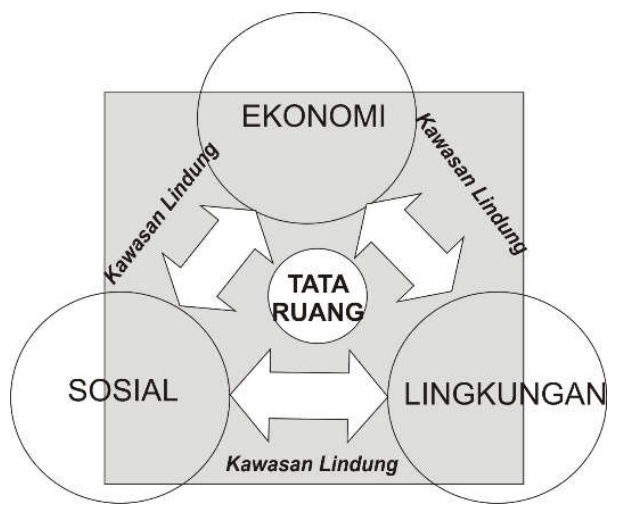

Sumber: Analisa dari World Commission on Environment and Development, 1987: Our Common Future

Gambar 1. Skema Pemanfaatan Ruang dalam Kawasan Lindung dan Kebijakan Tata Ruang

Pemanfaatan ruang yang tumpang tindih antara sosial, ekonomi dan lingkungan juga terjadi di Kawasan Cagar Alam Geologi Karangsambung (KCAGK), dengan indikasi masih adanya eksploitasi batuan yang dilakukan masyarakat di KCAGK. Kondisi tersebut disebabkan dorongan kebutuhan ekonomi masyarakat. Penambangan pasir dan batuan apabila dilakukan berlebihan berakibat pada kerusakan lingkungan (Puswanto et al, 2014). Dampak lain dari aktifitas penambangan berlebihan akan berakibat pada hilangnya geodiversity yang merupakan keunikan dari KCAGK. Keunikan bebatuan dari KCAGK dikarenakan pertemuan lempeng Indo-Australia dengan lempeng Benua Asia. Kawasan ini telah ditetapkan sebagai Kawasan Cagar Alam Geologi. Salah satu ketetapannya adalah melalui kebijakan Rencana Tata Ruang Wilayah Nasional, provinsi dan Kabupaten Kebumen. Kawasan yang semestinya steril dari kegiatan penambangan batuan, akan tetapi kenyataan di lapangan masih sering ditemukan kegiatan tersebut (lihat gambar 2). Kondisi tersebut akan berdampak pada berkurangnya dan bahkan hilangnya geodiversity di KCAGK.

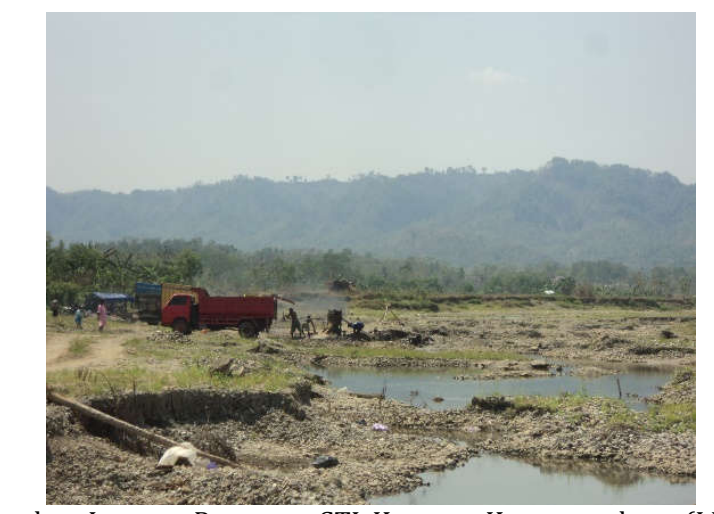

Sumber: Laporan Pemetaan GTL Kawasan Karangsambung (LIPI), 2017

Gambar 2. Aktivitas Tambang Illegal Pada Hilir Dan Hulu S. Luk Ulo

Penelitian sejenis di lokasi adalah: "Praktik Geowisata Karangsambung Kebumen Tinjauan Perspektif Dualitas" (Nugroho, 2016). Penelitian mempunyai latar belakang adanya ancaman kelestarian cagar alam geologi dikarenakan adanya 
penambangan rakyat. Rumusan masalah: 1) bagaimana praktik geowisata yang ada? 2) apa implikasi relasi tersebut bagi keberlanjutan praktik pariwisata di Karangsambung?. Metode yang digunakan adalah kualitatif. Hasil yang diperoleh berupa: 1) LIPI sebagai lembaga dengan fungsi ekosentris atau konservasi, 2) penambang mesin sebagai fungsi antroposentris dimana manusia sebagai sentris, 3) penambang manual sebagai fungsi ekonomenologis yaitu mempunyai kepentingan ekonomi dengan mempertimbangkan lingkungan. Rekomendasi berupa: 1) praktik akan geowisata seharusnya melibatkan peran masyarakat lokal dan 2) penambang mesin harus dihilangkan atau dihentikan.

Rumusan masalah dalam penelitian ini adalah kebijakan tata ruang berupa Peraturan Daerah RTRW dimana didalamnya mengamanatkan untuk melindungi KCAGK dari kepunahan geodiversity, akan tetapi pada implementasinya masih lemah terutama pada tahapan pengawasan. Indikasinya adalah adanya aktifitas penambangan batuan dan pasir di lokasi, yang dapat mengubah bentukan geologi dan merusak lingkungan.

Pertanyaan penelitian, faktor - faktor apa yang menyebabkan belum efektivnya pengawasan kebijakan RTRW dilihat dari aspek kelembagaan (LIPI dan BKPRD) dan keterlibatan masyarakat (tokoh masyarakat) pada kawasan lindung?

Tujuan dari penelitian ini adalah: 1) mengidentifikasi kebijakan penataan ruang dan karakteristik wilayah, 2) menganalisa dan merumuskan efektivitas pengawasan dari kebijakan penataan ruang melalui peran lembaga (LIPI dan BKPRD) dan masyarakat (tokoh masyarakat).

\section{Metode Atau Pendekatan Masalah}

Penelitian menggunakan metode kuantitatif, dimana pendekatan ilmiah dalam suatu tindakan untuk mengambil kebutuhan. Melalui metode tersebut diharapkan mampu menjawab tujuan dari penelitian ini yaitu: mengkaji efektivitas peran kelembagaan dan masyarakat dalam pengawasan kebijakan RTRW di KCAGK. Jenis penelitian menggunakan studi deskriptif eksploratif, dalam upaya memperoleh informasi deskripsi yang lengkap dan akurat akan kondisi yang ada dengan menggambarkan apa adanya suatu variabel tanpa menguji hipotesis menurut Boyd, et al (1989 dalam Kuncoro, 2011).

Variabel bebas penelitian diantaranya: 1) variabel kelembagaan dan 2) keterlibatan masyarakat. Variabel terikatnya adalah efektivitas pengawasan terhadap kebijakan penataan ruang (RTRW). Pemiliah variabel diatas didasarkan pada 1) pembatasan fokus penelitian, 2) terdapat lembaga LIPI pada lokasi penelitian yang mempunyai peran konservasi dan 3) adanya lembaga khusus dalam mengawal kebijakan RTRW yaitu BKPRD.
Tabel 1. Variabel Penelitan

\begin{tabular}{ccc}
\hline $\begin{array}{c}\text { Independent } \\
\text { Variable }\end{array}$ & $\begin{array}{c}\text { Dependent } \\
\text { Variable }\end{array}$ \\
\cline { 1 - 2 } $\begin{array}{c}\text { Kelembagaan } \\
\text { Keterlibatan } \\
\text { masyarakat }\end{array}$ & $\begin{array}{c}\text { Efektivitas } \\
\text { pengawasan }\end{array}$ \\
\cline { 2 - 2 } & $\begin{array}{c}\text { Intervening Variable } \\
\text { Budaya masyarakat } \\
\text { dalam perlindungan } \\
\text { lingkungan } \\
\text { Biaya }\end{array}$ & \\
& & \\
\hline
\end{tabular}

Klasifikasi variabel dan indikator dalam penelitian ini, dipilih 2 (dua) variabel yang akan diteliti yaitu berupa.

Tabel 2. Indikator Penelitan

\begin{tabular}{lll}
\hline $\begin{array}{c}\text { Klasifikasi } \\
\text { Sub } \\
\text { Variabel }\end{array}$ & \multicolumn{1}{c}{ Indikator } \\
\hline Kelembagaan & \\
\hline \multicolumn{3}{c}{ Peran Lembaga eksternal (LIPI): } \\
LIPI & 1. & Sosialisasi Kebijakan RTRW \\
& 2. & Perizinan penambangan \\
BKPRD & 3. & Insentif dan Disinsentif \\
& 4. & Pemantauan lingkungan \\
& 5. & Pembiayaan \\
\hline Masyarakat & 6. & Saran \\
\hline & Pemahaman dan Peran: \\
Tokoh & 1. & Pemahaman dan Sosialisasi \\
Masyarakat & 2. & Perizinan penambangan \\
& 3. & Insentif dan Disinsentif \\
& 4. & Pemantauan lingkungan \\
& 5. & Kepedulian lingkungan \\
\hline
\end{tabular}

Sampel responden kelembagaan diperoleh melalui teknik puposive sampling diperoleh 8 responden. Responden masyarakat diperoleh dengan diawali dengan menentukan zona sampling dan teknik random sampling, diperoleh 6 desa dalam 2 kecamatan yaitu Kecamatan Karangsambung dan Sadang. Tokoh masyarakat diperoleh dari informasi "key person" sebesar 20 orang, responden penambang melalui teknik rumus slovin diperoleh 31 responden.

Tahapan pengumpulan data dilakukan dengan mengisi kuesioner melalui wawancara langsung dengan responden dan untuk melengkapi kekurangan dilakukan dengan menggali informasi dari kerabat, tetangga dan pimpinan responden.

\section{Hasil dan Pembahasan}

\subsection{Gambaran Lokasi KCAGK}

Kawasan Cagar Alam Geologi Karangsambung di Kabupaten Kebumen terletak di 6 (enam) kecamatan, yaitu: Karanggayam, Alian, Sadang, Karangsambung, Sruweng dan Pejagoan. Luasan lahan \pm 22.154 ha, dengan Desa Karangsambung berada di pusat kawasan. Secara geogafis kawasan memiliki karakteristik lembah dan perbukitan bagian dari Pegunungan Serayu Selatan. Potensi geodiversity pemanfaatannya di golongkan menjadi 2 (dua) yaitu 
1) geodiversity yang tidak dilindungi dan 2) geodiversity yang dilindungi, total jumlah lokasi geodiversity di KCAGK sejumlah 32 lokasi batuan, lihat gambar 3.

\subsection{Identifikasi Kebijakan penataan ruang di KCAGK}

Pada Tahun 2008, berdasarkan RTRWN (Rencana Tata Ruang Wilayah Nasional) melalui PP (Peraturan Pemerintah) No 26 Tahun 2008 menetapkan kawasan lindung geologi sebagai salah satu kawasan lindung nasional. Berikutnya pada Tahun 2010 melalui RTRW (Rencana Tata Ruang Wilayah) Provinsi Jawa Tengah dengan Peraturan Daerah Nomor 6 Tahun 2010 ditegaskan kembali akan Kawasan Cagar Alam Geologi Karangsambung. Terakhir pada Tahun 2012 melalui RTRW (Rencana
Tata Ruang Wilayah) Kabupaten Kebumen melalui Peraturan Daerah Nomor 23 Tahun 2012.

RTRW Kabupaten adalah kawasan strategis menurut perlindungan lingkungan. Dalam ketentuan umum peraturan zonasi, menyatakan kawasan lindung Cagar Alam Geologi Karangsambung disusun dengan ketentuan: 1) dilarang melakukan kegiatan yang mengubah bentukan geologi tertentu yang mempunyai manfaat untuk pengembangan ilmu pengetahuan, perlindungan flora dan fauna, serta pelestarian air; dan 2) memperhatikan persyaratan pendirian bangunan yang menunjang kegiatan pendidikan, penelitian dan wisata. Masih dalam muatan RTRW kabupaten juga mengatur akan: 1) Ketentuan Perizinan, 2) Ketentuan Pemberian Insentif dan Disinsentif, 3) Peran Serta Masyarakat dan 4) Kelembagaan.

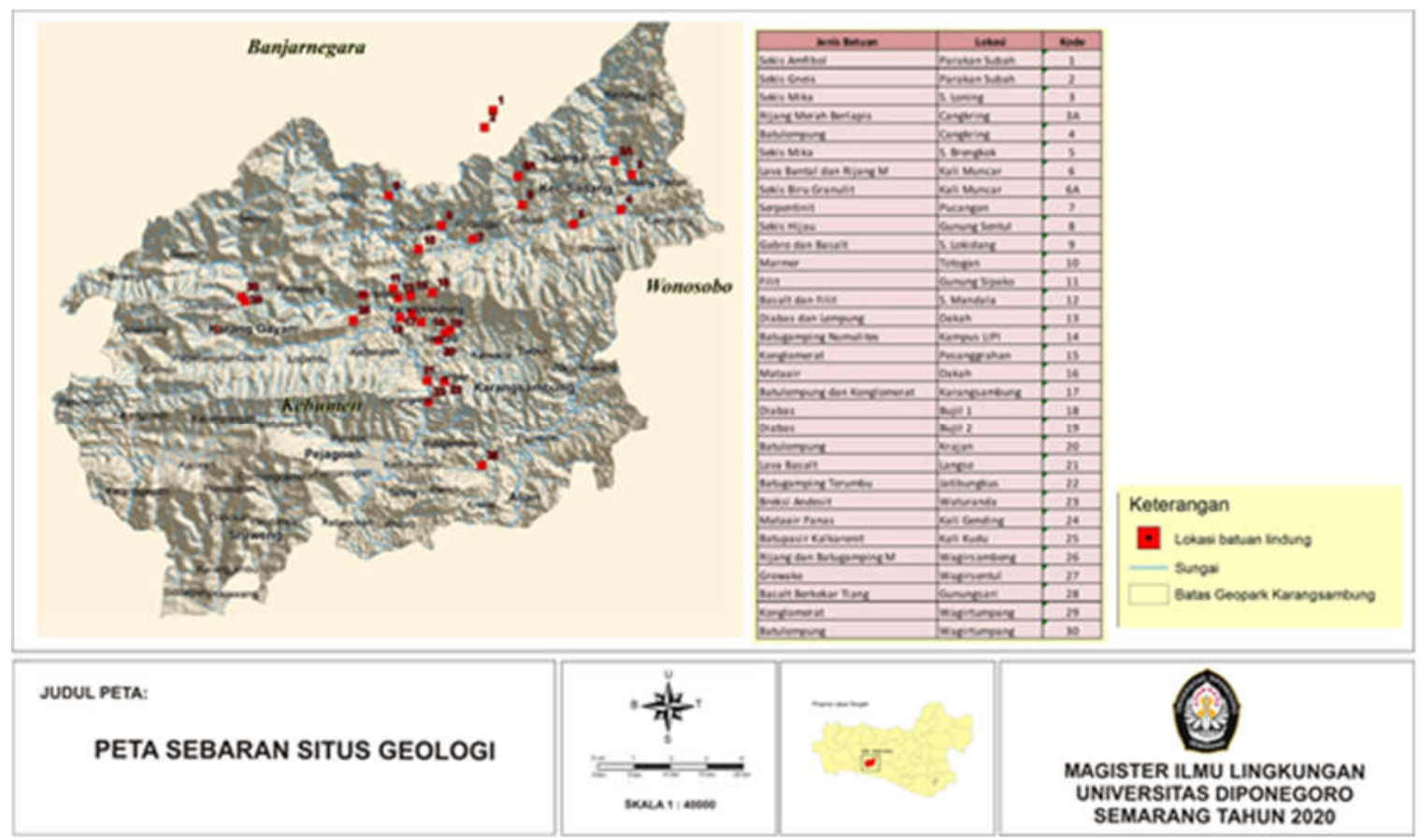

Sumber: Laporan Pemetaan GTL Kawasan Karangsambung (LIPI), 2017

Gambar 3. Aktivitas Tambang Illegal Pada Hilir Dan Hulu S. Luk Ulo

\subsection{Peran Masyarakat dalam Pengawasan}

Responden berjumlah 20 orang, seluruh responden berjenis kelamin laki-laki, usia responden terbanyak pada usia 31-50 tahun (70\%), jenjang pendidikan akhir responden terbanyak di tingkatan SLTA (74\%), posisi responden di masyarakat adalah sebagai tokoh masyarakat dan ketua RT/RW total sebesar $60 \%$ dengan posisi lain-lain sebesar $40 \%$

Pemahaman akan kebijakan RTRW hampir mayoritas tidak mengetahui, hanya sekitar 25\% yang mengetahui, akan tetapi semua responden mengetahui adanya KCAGK di lokasi mereka. Kurangnya sosialisasi juga dirasakan responden, sehingga sebagian besar (76\%) menjawab sosialisasi belum efektiv. Lihat pada tabel 3 .
Tabel 3. Pemahaman dan Sosialisasi Perda RTRW (Responden Tokoh Masyarakat)

\begin{tabular}{|c|c|c|}
\hline \multirow[t]{3}{*}{ I.A } & Pemahaman Terhadap Perda RTRW? & $\%$ \\
\hline & a. Mengerti & 30 \\
\hline & b. Tidak & 70 \\
\hline \multirow[t]{3}{*}{ I.B } & Pemahaman Terhadap KCAGK? & $\%$ \\
\hline & a. Mengerti & 95 \\
\hline & b. Tidak & 5 \\
\hline \multirow[t]{3}{*}{ I.C } & Adakah Sosilisasi RTRW? & $\%$ \\
\hline & a. Ada & 15 \\
\hline & b. Tidak ada & 85 \\
\hline \multirow[t]{3}{*}{ I.D } & Bentuk Sosialisasi? & $\%$ \\
\hline & a. $\quad$ FGD / Diskusi & 15 \\
\hline & b. Iklan & 0 \\
\hline \multirow[t]{3}{*}{ I.E } & Apakah sudah tepat sosilisasi? & \\
\hline & a. Sudah & 0 \\
\hline & b. Belum & 100 \\
\hline
\end{tabular}


Rendahnya masyarakat dalam pemahaman kebijakan Peraturan Daerah RTRW dapat dikaitkan dengan tidak diikutsertakannya masyarakat dalam proses kebijakan publik yaitu: 1) konsep kebijakan, 2) implementasi kebijakan dan 3) evaluasi kebijakan (Herdiana, 2018). Sesuai pendapat tersebut bahwa hasil responden mayoritas belum mendapat sosialisasi, sedangkan keberadaan LIPI menjadi alasan masyarakat mengetahui adanya KCAGK.

Pada indikator perizinan tambang, rata-rata menjawab proses yang sulit (45\%) dan memahami jika tidak ada izin yang diberikan untuk penambangan di KCAGK (45\%). Lihat pada tabel 4.

Pelimpahan kewenangan dalam proses perizinan penambangan yang merupakan urusan pusat dengan dikelola oleh provinsi mengakibatkan 1) tanggungan dan beban menjadi lebih berat, 2) sosialisasi dan pengawasan menjadi lemah, 3) meningkatnya jumlah penambang ilegal dan 4) proses periznan yang lebih lama (Yoga \& Waskita, 2014).

Tabel 4. Perizinan Penambangan

(Responden Tokoh Masyarakat)

\begin{tabular}{|c|c|}
\hline $\begin{array}{l}\text { II. Tingkat kesulitan prosedur perizinan } \\
\text { penambangan di KCGK }\end{array}$ & $\%$ \\
\hline a. Mudah & $5 \%$ \\
\hline b. Sulit & $45 \%$ \\
\hline c. Tidak ada izin lagi di KCAGK & $45 \%$ \\
\hline
\end{tabular}

Indikator penerapan insentif dan disinsentif mayoritas masyarakat sudah memahami $(85 \%)$ akan tetapi penerapannya dilapangan hampir seluruh responden menjawab belum ada penerapan (95\%). Lihat pada tabel 5.

Konflik ruang antar wilayah, sektor dan masyarakat dengan pemerintah dikarenakan belum optimalnya implementasi penegakan hukum (disinsentif) berdasarkan penataan ruang (Junef, 2017). Minimnya pemahaman dan lemahnya penerapan insentif dan disinsentif terhadap kebijakan RTRW di KCAGK berpotensi adanya konflik kepentingan.

Tabel 5. Pemahaman dan Penerapan Insentif dan Diinsentif Responden (Tokoh Masyarakat)

\begin{tabular}{rlr}
\hline III.A & Apakah memahami & $\%$ \\
\hline a & Mengerti & $85 \%$ \\
b & Tidak & $10 \%$ \\
\hline III.B & Apakah sudah dilakukan & $\%$ \\
\hline a & Sudah & $0 \%$ \\
b & Belum & $95 \%$ \\
c & Tidak Tahu & $5 \%$ \\
\hline
\end{tabular}

Kondisi lingkungan yang buruk di KCAGK dirasakan masyarakat, sedangkan keterlibatan masyarakat dalam memantau kondisi lingkungannya sudah dilakukan selama ini. Beberapa keterlibatan masyarakat dalam memantau lingkungan disekitarnya jika ditemukan permasalahan sebagaian besar melalui himbauan (45\%) dan melakukan pelaporan ke desa (30\%). Lihat tabel 6 .
Akses informasi yang penting dalam kemungkinan pengambilan keputusan adalah salah satu pentingnya keterlibatan masyarakat dalam pengelolaan lingkungan hidup (Edorita, 2006). Peran masyarakat melalui tokoh masyarakat dalam pemantauan lingkungan merupakan potensi yang dapat diangkat lebih dengan memberikan kewenangan yang lebih.

\begin{tabular}{rlc}
\multicolumn{3}{c}{$\begin{array}{c}\text { Tabel 6. Pemantauan Lingkungan } \\
\text { (Responden Tokoh Masyarakat) }\end{array}$} \\
\hline IV.A & Apakah ada kerusakan lingkungan? & $\%$ \\
\hline a & Ada & $100 \%$ \\
b & Tidak ada & $0 \%$ \\
\hline \multirow{2}{*}{ IV,B } & Keterlibatan dalam memantau & \\
\hline & lingkungan & $100 \%$ \\
a & Ada & $0 \%$ \\
b & Tidak ada & \\
\hline \multirow{2}{*}{ IV.C } & Jika ada, dalam bentuk apa & keterlibatannya? \\
\hline a & Himbauan (peringatan langsung) & $45 \%$ \\
b & Pelaporan (kepada lembaga desa) & $30 \%$ \\
c & Tindakan (pencegahan, perbaikan) & $10 \%$ \\
d & Lain-lain & $15 \%$ \\
\hline
\end{tabular}

Indikator kepedulian lingkungan dalam mendukung pengawasan Perda RTRW, sudah dilakukan melalui kegiatan menjaga lingkungan dari kerusakan dalam bentuk bersih lingkungan (gotong royong). Lihat Tabel 7.

Pandangan akan alam bukan hanya sumber kehidupan tetapi merupakan media pembelajaran, sehingga masyarakat memiliki budaya yang mengedepankan keharmonisan alam dan melakukan tindakan perlindungan terhadap lingkungan (Sabardi, 2014). Potensi keterlibatan masyarakat terhadap pemantauan lingkungan dapat digali dari kearifan lokal yang pada dasarnya mempunyai kepedulian dalam menjaga lingkungan.

Tabel 7. Kepedulian Lingkungan (Responden Tokoh Masyarakat)

\begin{tabular}{|c|c|c|}
\hline V.A & $\begin{array}{l}\text { Apakah ada tindakan menjaga } \\
\text { lingkungan? }\end{array}$ & $\%$ \\
\hline $\mathrm{a}$ & Ada & $100 \%$ \\
\hline $\mathrm{b}$ & Tidak Ada & $0 \%$ \\
\hline V.B & Jika ada, dalam bentuk apa? & \\
\hline $\mathrm{a}$ & Bersih Lingkungan & $100 \%$ \\
\hline $\mathrm{b}$ & Sosialisasi & $0 \%$ \\
\hline $\mathrm{c}$ & Pelaporan & $0 \%$ \\
\hline
\end{tabular}

\subsection{Kelembagaan dalam pengawasan}

LIPI, sebagai pengelola di KCAGK untuk fungsi pendidikan dan konservasi. Struktur organisasi di UPT BIKK Karangsambung LIPI mempunyai jumlah 58 personil, dengan jumlah tenaga teknis diantaranya ketua LIPI 1 personil, tenaga peneliti sebanyak 11 personil, teknisi litkayasa sejumlah 8 personil.

BKPRD Kabupaten Kebumen, terdiri dari 2 penanggung jawab, 1 ketua dan sekertaris, serta 10 anggota. Dalam susunan keorganisasi BKPRD dibentuk 2 kelompok kerja (pokja) diantaranya: 1) 
pokja perencanaan tata ruang BKPRD dan 2) pokja pemanfaatan dan pengendalian pemanfaatan ruang BKPRD, dimana masing-masing pokja terdapat 12 personil yang setingkat kepala bidang, kepala bagian, kepala sub bidang dan kepala seksi. Pembentukan BKPRD pada tingkat kabupaten diterjemahkan berdasarkan tujuan mendukung aturan atau kebijakan penataan ruang yang sudah ada, sehingga badan bersifat ad hoc (bersifat antara)

1. Sosialisasi Kebijakan RTRW

Kegiatan sosialisasi selama ini telah dilakukan sebagian besar melalui rapat / FGD, sedagkan sisanya melalui media sosial, penyuluhan dan iklan terbuka, lebih jelasnya lihat tabel 8.

Lemahnya sistem informasi penataan ruang merupakan keterbatasan informasi sehingga berdampak pada tidak optimalnya tahapan sosialisasi kebijakan RTRW, selain itu belum adanya keterlibatan masyarakat (Rini S. Saptaningtyas, 2003).

Tabel 8. Sosialisasi Perda RTRW (Responden Kelembagaan)

\begin{tabular}{llcc}
\hline A. & $\begin{array}{l}\text { Dalam bentuk apa sosialisasi } \\
\text { dilakukan? }\end{array}$ & $\begin{array}{l}\text { LIPI } \\
(\%)\end{array}$ & $\begin{array}{c}\text { BKPRD } \\
(\%)\end{array}$ \\
\hline $\begin{array}{l}\text { 1. } \\
\text { 2. Rapat / FGD }\end{array}$ & $42 \%$ & $40 \%$ \\
& $\begin{array}{l}\text { Media Sosial (Teknologi } \\
\text { 3. Iklan terbuka } \\
\text { (media visual luar) }\end{array}$ & $33 \%$ & $22 \%$ \\
& $\begin{array}{l}\text { Langsung ke lapangan } \\
\text { (penyuluhan) }\end{array}$ & $25 \%$ & $16 \%$ \\
\hline \multicolumn{1}{c}{ Total } & $100 \%$ & $100 \%$ \\
\hline
\end{tabular}

\section{Perizinan penambangan}

Pemberian perizinan di KCAGK sebagian besar berpendapat tidak mudah dan sudah tidak ada izin yang diberikan untuk penambangan, sedangkan untuk peran yang dilakukan kelembagaan di LIPI dan BKPRD adalah dengan memberikan arahan atau rekomendasi, lihat pada tabel 9. Proses perizinan yang rumit dan menurunnya perizinan akan menambah penambangan ilegal di lokasi penambangan tersebut (Yoga \& Waskita, 2014).

Tabel 9. Perizinan Penambangan (Responden Kelembagaan)

\begin{tabular}{|c|c|c|c|}
\hline \multicolumn{4}{|c|}{ (Responden Kelembagaan) } \\
\hline B.1. & $\begin{array}{l}\text { Bagaimana dengan } \\
\text { perizinan yang ada? }\end{array}$ & $\begin{array}{l}\text { LIPI } \\
(\%)\end{array}$ & $\begin{array}{l}\text { BKPRD } \\
(\%)\end{array}$ \\
\hline & 1.Tidak Mudah / Sulit & $75 \%$ & $0 \%$ \\
\hline & 2.Mudah & $0 \%$ & $25 \%$ \\
\hline & 3.Tidak ada izin & $25 \%$ & $75 \%$ \\
\hline & 4.Tidak Tahu & $0 \%$ & $0 \%$ \\
\hline \multicolumn{2}{|c|}{ Total } & $100 \%$ & $100 \%$ \\
\hline \multirow[t]{5}{*}{ B.2. } & $\begin{array}{l}\text { Peran lembaga dalam } \\
\text { pelaksanaan perizinan? }\end{array}$ & $\begin{array}{l}\text { LIPI } \\
(\%)\end{array}$ & $\begin{array}{l}\text { BKPRD } \\
(\%)\end{array}$ \\
\hline & 1. Arahan /rekomendasi & $100 \%$ & $100 \%$ \\
\hline & 2. Memantau aktifitas & $0 \%$ & $0 \%$ \\
\hline & 3. Tidak ada peran & $0 \%$ & $0 \%$ \\
\hline & 4. Tidak Tahu & $0 \%$ & $0 \%$ \\
\hline \multicolumn{2}{|c|}{ Total } & $100 \%$ & $100 \%$ \\
\hline
\end{tabular}

Masih adanya penambangan ilegal merupakan indikasi dari lemahnya pegawasan sehingga meskipun izin penambangan sudah tidak ada.

\section{Pemberian Insentif dan disinsentif}

Pernyataan yang sama diungkapkan kelembagaan di LIPI dan BKPRD bahwa penerapan intensif dan disinsentif penting akan tetapi belum diterapkan secara baik di lapanganan, lihat tabel 10 . Kelengkapan dalan penerapan insentif dan disinsentif adalah dengan dipenuhinya tujuan, mekanisme dan arahan penerapannya. Pada aspek pendanaan insentif lebih didominasi dari APBD dan APBN sedangkan alternatif yang bisa digali dari masyarakat dan CSR badan usaha (Pramudita, 2015).

Tabel 10. Penerapan Insentif dan Disinsentif (Responden Kelembagaan)

\begin{tabular}{|c|c|c|}
\hline C.1. Apakah penting & LIPI (\%) & BKPRD (\%) \\
\hline 1. Penting & $50 \%$ & $100 \%$ \\
\hline 2. Kurang Penting & $25 \%$ & $0 \%$ \\
\hline 3. Tidak Perlu & $25 \%$ & $0 \%$ \\
\hline 4. Tidak Tahu & $0 \%$ & $0 \%$ \\
\hline Total & $100 \%$ & $100 \%$ \\
\hline $\begin{array}{ll}\text { C.2. } & \begin{array}{l}\text { Apakah sudah } \\
\text { diterapkan? }\end{array} \\
\end{array}$ & LIPI (\%) & $\begin{array}{c}\text { BKPRD } \\
(\%)\end{array}$ \\
\hline 1. Sudah & $0 \%$ & $25 \%$ \\
\hline 2. Sebagian & $0 \%$ & $0 \%$ \\
\hline 3. Belum & $100 \%$ & $75 \%$ \\
\hline 4. Tidak Tahu & $0 \%$ & $0 \%$ \\
\hline Total & $100 \%$ & $100 \%$ \\
\hline
\end{tabular}

\section{Pemantauan Lingkungan}

Keterlibatan dari kelembagaan yang ada (LIPI dan BKPRD) dalam pemantauan lingkungan di KCAGK kedua lembaga sudah melaukannya. Dalam bentuk pemantauan lingkungan yang dilakukan di BKPRD yaitu terlibat langsung dalam penyuluhan dan pemantauan, sedangkan di LIPI lebih cenderung dengan melakukan penelitian-penelitian yang terkait. Lebih jelasnya dapat dilihat pada tabel 11 .

Lemahnya penataan hukum lingkungan terutama pada penindakan terhadap pelaku yang merusak lingkungan hidup, sehingga perlu adanya pembenahan kelembagaan yang berpihak kepada aspirasi masyarakat (Sugiyono, 2002). Minimnya tindakan pemantauan lingkungan yang dilakukan lembaga terkait perlu dilakukan evaluasi dengan penguatan lembaga dalam personil, jaringan kelembagaan dan pendanaan.

Tabel 11. Pemantauan Lingkungan (Responden Kelembagaan)

\begin{tabular}{lrr}
\hline $\begin{array}{l}\text { D. Jika ada, dalam bentuk } \\
\text { apa pemantauan }\end{array}$ & $\begin{array}{c}\text { LIPI } \\
\text { lingkungan? }\end{array}$ & \multicolumn{1}{c}{$\begin{array}{c}\text { BKPRD } \\
\text { (\%) }\end{array}$} \\
\hline 1. Terlibat langsung & $25 \%$ & $100 \%$ \\
2. Memberikan laporan & $25 \%$ & $0 \%$ \\
3. Melakukan penelitian & $50 \%$ & $0 \%$ \\
4. Lain-lain & $0 \%$ & $0 \%$ \\
\hline Total & $100 \%$ & $100 \%$ \\
\hline
\end{tabular}


5. Pembiayaan

Pada indikator pembiayaan untuk pelaksanaan pengawasan kebijakan RTRW sebagian besar diperoleh dari anggaran rutin dan sebagaian menjawan tidak ada anggaran khusus. Lihat pada tabel 12.

Kualitas kinerja pada sebuah lembaga akan meningkat dimana ada kejelasan akan sasaran anggaran yang ada, atau dalam kata lain kejelasan anggaran mempunyai pengaruh positif terhadap kinerja lembaga atau pemerintah daerah (Suwandi, 2013). Anggaran yang masih minim untuk pengawasan lingkungan dirasa masih menjadi kendala di kedua lembaga dalam pengawasan lingkungan di KCAGK.

Pendanaan merupakan salah satu indikator yang seharusnya menjadi jawaban akan ketidakefektivan pengawasan kebijakan RTRW.

Tabel 12. Pembiayaan (Responden Kelembagaan)

\begin{tabular}{|c|c|c|c|}
\hline E. & $\begin{array}{l}\text { Pendanaan pengawasan } \\
\text { dari mana sumbernya? }\end{array}$ & $\begin{array}{l}\text { LIPI } \\
(\%)\end{array}$ & $\begin{array}{c}\text { BKPRD } \\
(\%)\end{array}$ \\
\hline & 1. Alokasi anggaran rutin & $75 \%$ & $50 \%$ \\
\hline & Dana CSR & $0 \%$ & $0 \%$ \\
\hline & 3. Pribadi / personal & $0 \%$ & $0 \%$ \\
\hline & 4. Tidak ada alokasi & $25 \%$ & $50 \%$ \\
\hline Tot & & $100 \%$ & $100 \%$ \\
\hline
\end{tabular}

6. Saran atau masukan responden

Saran responden OPD terkait dengan pengawasan lingkungan atas kebijakan RTRW sebagian besar menyrankan adanya: 1) peran masyarakat lokal perlu diperkuat dalam pengawasan (36.4\%), 2) alokasi dana yang cukup (27.3\%), serta 3) adanya sinergi kelembagaan (27,3\%). Lihat Tabel 13.
Peran partisipasi masyarakat dalam penyelenggaraan penataan ruang di kawasan lindung diantaranya: 1) menjaga dan melestarikan lingkungan melalui peningkatan partisipasi masyarakat dan 2) keterlibatan masyarakat lokal dalam melindungi kawasan dan peningkatan usaha lokal (Zuhri \& Sulistyawati, 2007). Pentingnya peran dan keterlibatan dari masyarakat menjadi salah satu kunci peningkatan pengawasan kebijakan RTRW di KCAGK. Keterlibatan yang besar dari masyarakat dipahami karena kedekatan dengan lokasi dan keterikatan sosial budaya setempat.

Tabel 13. Saran atau Masukan (Responden Kelembagaan)

\begin{tabular}{clr}
\hline a. & Memperbanyak sosialisasi & $27.3 \%$ \\
\hline b. & Memperuat pengawasan dari masyarakat & $36.4 \%$ \\
\hline c. & Ada alokasi dana dalam pengawasan & $9.1 \%$ \\
\hline d. & Pemerintah daerah terlibat langsung dalam & \\
& pengawasn & $0.0 \%$ \\
\hline e. & Penegakan hukum & $0.0 \%$ \\
\hline f. & Peningktan peran CSR & $0.0 \%$ \\
\hline g. & sinergi kelembagaan & $27.3 \%$ \\
\hline
\end{tabular}

\subsection{Rumusan Pengawasan dalam Tahapan Implementasi Penyelenggaraan Penataan Ruang di KCAGK}

Tahapan terakhir sesuai dengan keluaran dan sasaran penelitian ini adalah adanya suatu rumusan atau formulasi pengawasan terhadap Perda RTRW di KCAGK. Berikut ini rumusan yang menjadi arahan tiap prosesnya:

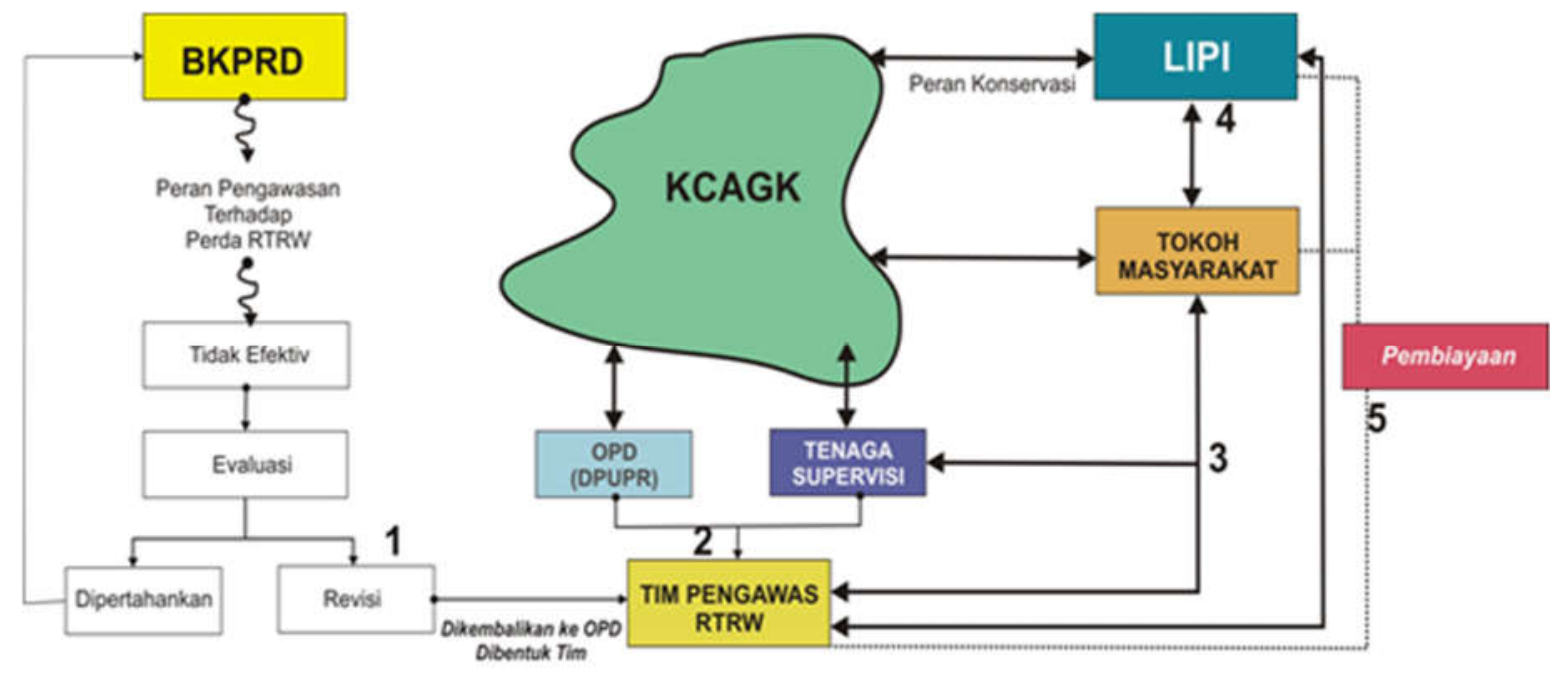

Gambar 4. Aktivitas Tambang Illegal Pada Hilir Dan Hulu S. Luk Ulo

Peran BKPRD yang masih rendah menunjukan tidak efektivnya lembaga ini didalam menjalankan tupoksinya, sehingga perlu ada evaluasi yang merekomendasikan untuk direvisi keberadaan dari BKPRD.

1) Sebagai solusi dari dihilangkannya lembaga BKPRD dalam peran pengawasan, diusulkan untuk dikembalikan ke tupoksi OPD yang berkaitan dengan bidang penataan ruang yaitu Dinas PUPR. Keberadan dinas PUPR didukung dengan tenaga lapangan "supervisor" (khusus membantu kegiatan-kegiatan pengawasan) yang dikontrak secara profesional, sehingga kedudukannya sebagai "Tim Pengawasan Perda RTRW". 
2) Keterlibatan tokoh masyarakat bersama dengan struktur organisasi di desa dan kecamatan. Tokoh masyarakat dipilih berdasarkan musyawarah desa, dengan memberikan perannya sebagai penghubung informasi lapangan dengan lembaga LIPI, Tim pengawas Perda RTRW maupun secara personal bisa langsung ke tenaga lapangan supervisor. Selain sebagai penghubung informasi, tokoh masyarakat sebagai ujung tombak dari kegiatan sosialisasi, pengawasan dan aktifitas lainnya dalam mendukung dan menjaga fungsi lindung di KCAGK.

3) LIPI Karangsambung mealalui tupoksinya sebagai fungsi konservasi di KCAGK, secara perannya dapat dioptimalkan dengan keterlibatannya sebagai penghubung informasi dan kegiatankegiatan dalam pengawasan Perda RTRW. Koordinasi perlu dilakukan LIPI melalui tokoh masyarakat, tim pengawasa Perda RTRW atau dengan tenaga lapangan supervisor.

4) Pembiayaan merupakan bentuk penghargaan pemerintah pusat atau daerah akan keterlibatan pelaku pengawasan dan sebagai sarana untuk kelancaran kegiatan-kegiatan yang ada. Pembiayaan ini diharapkan tidak menjadi pertimbangan yang utama, bentuk pembiayaan diprioritaskan untuk kegiatan-kegiatan yang penting dalam menjaga keberlanjutan di KCAGK.

\section{Kesimpulan}

Permasalahan penelitian adalah konflik ruang kawasan lindung dengan budidaya di KCAGK dan diindikasi tidak berjalan sesuai kebijakan RTRW. Penelitian ini telah mengurai masalah konflik ruang pada aspek pengawasan yang tidak berjalan, khususnya lembaga yang ada (BKPRD dan LIPI), peran masyarakat.

Dari hasil analisis, disimpulkan bahwa tingkat efektivitas pengawasan Perda RTRW di KCAGK pada lembaga BKPRD sangat rendah (hampir tidak ada aksi nyata), peran LIPI Karangsambung sudah berjalan sesuai tupoksinya, akan tetapi masih belum didukung koordinasi yang baik dengan lembaga pengawas dari Pemerintah Kabupaten Kebumen dan Provinsi Jawa Tengah.

Peran masyarakat melalui pimpinan dan tokoh lokal tidak efektiv dan dijumpai beberapa kendala yaitu ketidaktahuan peran yang dilakukan dan wadah atau organisasi khusus dalam pengawasan lingkungan.

\section{Ucapan Terima Kasih}

Penulis mengucapkan penghargaan dan terimakasih kepada LIPI Karangsambung dan Pemerintah Daerah Kabupaten Kebumen.

\section{DAFTAR PUSTAKA}

Absori, (2006)." Pemberdayaan Masyarakat Melalui Penguatan Otonomi Masyarakat Dalam Penyelesaian Sengketa Lingkungan Hidup." Humaniora, 7(1), 5267.
Arba, 2017, Hukum Tata Ruang dan Tata Guna Tanah, Sinar Grafika, Jakarta.

Herdiana, D. (2018). Sosialisasi Kebijakan Publik: Pengertian dan Konsep Dasar. Jurnal Ilmiah Wawasan Insan Akademik, 1(3), 2-15.

Edorita Widia. (2006). Peran Serta Masyarakat Terhadap Lingkungan Menurut Uu No.32 Tahun 2009 Tentang Perlindungan Dan Pengelolaan Lingkungan Hidup, jurnal ilmu hukum 76, 4(1), 76-99.

Junef, M. (2017). Penegakan Hukum dalam Rangka Penataan Ruang Guna Mewujudkan Pembangunan Berkelanjutan. Jurnal Penelitian Hukum De Jure, 17(4), 373.

https://doi.org/10.30641/dejure.2017.v17.373-390

Keeble, B. R. (1988). The Brundtland Report: "Our Common Future." Medicine and War, 4(1), 17-25. https://doi.org/10.1080/07488008808408783

Kuncoro, M. (2011). Metode Kuantitatif. Yogyakarta: UPP STIM YKPN.

Suwandi Anisa P, (2013). Pengaruh Kejelasan Sasaran Anggaran Dan Desentralisasi Terhadap Kinerja Pemerintah Daerah (Studi Empiris pada SKPD Pemerintah Kota Padang), . UNP Padang.

Nugroho, S. (2016). Praktik Geowisata Karangsambung Kebumen: Tinjauan Perspektif Dualitas. Jurnal Master Pariwisata (JUMPA), 3, 92-114. https://doi.org/10.24843/jumpa.2016.v03.i01.p07

Pramudita, D. (2015). Insentif dalam perlindungan lahan pertanian pangan berkelanjutan di kabupaten kuningan danang pramudita. Tesis Pascasarjana IPB Bogor.

Puswanto, E., Raharjo, P. D., \& Widiyanto, K. (2014). Identifikasi Kerusakan Das Luk Ulo Dan Upaya Pemberdayaan Masyarakat (Studi Kasus: Karangsambung, Kabupaten Kebumen). Prosiding Seminar Nasional Kebumian Ke-7, 25-33. Retrieved from https://repository.ugm.ac.id/135120/1/25-33 P10-03.pdf

Rini S. Saptaningtyas. (2003). Kajian Penyusunan Dan Implementasi Rencana Tata Ruang Wilayah Kabupaten Se Pulau Sumbawa Propinsi Nusa Tenggara Barat. DIMENSI (Jurnal Teknik Arsitektur), 31(2), 133-140. Retrieved from http://puslit2.petra.ac.id/ejournal/index.php/ars/ar ticle/view/16166

Sabardi, L.-. (2014). Peran Serta Masyarakat Dalam Pengelolaan Lingkungan Hidup Menurut UndangUndang Nomor 32 Tahun 2009 Tentang Perlindungan Dan Pengelolaan Lingkungan Hidup. Yustisia Jurnal Hukum, 3(1), 67-79. https://doi.org/10.20961/yustisia.v3i1.10120

Segura, S., \& Pedregal, B. (2017). Monitoring and evaluation framework for spatial plans: A Spanish case study. Sustainability (Switzerland), 9(10). https://doi.org/10.3390/su9101706

Sugiyono, A. (2002). Kelembagaan Lingkungan Hidup di Indonesia *). Kelembagaan Lingkungan Hidup Di Indonesia, (August), 1-16. https://doi.org/10.13140/2.1.1706.6881

Tejedor-Flores, N., Galindo-Villardón, P., \& Vicente-Galindo, P. (2017). Sustainability multivariate analysis based on the global reporting initiative (GRI) framework, using as a case study: Brazil compared to Spain and Portugal. International Journal of Sustainable Development and Planning, 12(4), 667-677. https://doi.org/10.2495/SDP-V12-N4-667-677

Von Der Dunk, A., Grêt-Regamey, A., Dalang, T., \& 
Hersperger, A. M. (2011). Defining a typology of periurban land-use conflicts - A case study from Switzerland. Landscape and Urban Planning, 101(2), 149-156.

https://doi.org/10.1016/j.landurbplan.2011.02.007
Yoga, K., \& Waskita, D. (2014). Implementasi Perizinan Galian C di Sungai Luk Ulo Kbupaten Kebumen, 1-15.

Zuhri, M., \& Sulistyawati, E. (2007). Protection Management of Mount Papandayan. Energy, (3). 